\title{
Análise das estruturas arco de desinfecção, rodolúvio e pedilúvio como barreiras sanitárias em tempos de pandemia
}

\section{Analysis of the structures "arco de desinfecção, rodolúvio and pedilúvio" as sanitary barriers in pandemic times}

\author{
Ivanilson Souza ${ }^{1}$; Cecília de Fátima Souza Ferreira ${ }^{2}$
}

\begin{abstract}
RESUMO: Dada a urgência de abordagens sólidas sobre o novo coronavírus, o presente artigo faz uma reflexão sobre três estruturas que são barreiras sanitárias: o arco de desinfecção, o pedilúvio e o rodolúvio. O estudo comprova a falta de referências científicas sobre tais estruturas e suas aplicações e, menos ainda, a relativa eficácia em ocasiões específicas. Observou-se também, nas poucas referências encontradas, uma nomenclatura equivocada, demonstrando falta de fundamento até nas etimologias. Ficou claro ainda, que não há normas específicas referentes à confecção dessas estruturas e, nem testes sobre a eficiência de cada uma delas. O que se fez aqui foi um esforço para, apesar da abordagem comum nas Ciências Agrárias, tentar preencher uma lacuna no resgate sobre a importância dessas barreiras, ainda mais em razão do momento atual de enfrentamento do novo coronavírus.
\end{abstract}

PALAVRAS-CHAVE: construções rurais; formas de desinfecção; coronavírus.

\begin{abstract}
Given the urgency of solid approaches about the new coronavirus, this article a sociological reflection is made on three structures that are sanitary barriers: "the arco de desinfecção, the rodolúvio and the pedilúvio". This study proved the lack of scientific references on such structures and their applications and, even less, the relative effectiveness when applied on specific occasions. It was also observed, in the few literature found, the mistaken nomenclatures, showing a lack of knowledge even in the etymologies. It was also clear that there are no specific rules regarding the construction of these structures, nor tests on the efficiency of each one. What is being done here is an effort to try, despite the common approach in Agrarian Sciences, to fill a gap in the rescue of the importance of these barriers, especially because of the current moment of the new coronavirus.
\end{abstract}

KEY WORDS: farm buildings; disinfection ways; coronavirus.

1 - Sociólogo - ivanilson.souza@ hotmail.com. No momento não está vinculado a instituições de ensino ou pesquisa.

2 - Professor - Departamento de Engenharia Agrícola/UFV - Av. PH Rolfs s/n - Viçosa/MG - 36570-900 - cfsouza@ufv.br 


\section{INTRODUÇÃO}

A observação da barreira sanitária revela que é usada para fazer referência a mecanismos governamentais ou privados e estruturas físicas utilizadas para restringir a circulação de pessoas, meios de transportes, etc., impedir a proliferação de vetores e controlar a disseminação de doenças. Ao discorrer sobre as barreiras sanitárias arco de desinfecção, pedilúvio e rodolúvio, este artigo mostra um esforço para coletar informações sobre tais estruturas e para entender as razões pelas quais não fazem parte de uma política pública de saúde que ajudaria no combate ao novo coronavírus.

O estudo destaca o arco de desinfecção que, em razão de sua especificidade para desinfetar veículos antes de entrarem em espaços de criação de animais, de cultivos de plantas, da indústria alimentícia, etc., poderá ser usado para desinfetar os veículos que trafegam por rodovias estaduais e federais de entrada e saída do Estado do Maranhão. Dentre as três barreiras o arco é a mais engenhosa, embora não seja obra da engenharia científica. É uma barreira produzida por indústrias de pequeno porte e, tal qual as outras duas, sem um estudo que garanta sua eficácia ou eficiência.

Devido a essa falta de estudos é que se pretende, com este artigo, contribuir para o surgimento de pesquisas que comprovem, ou não, se os arcos vendidos no país, de fato desinfetam. Espera-se também subsidiar agentes públicos (AGED ${ }^{1}, \mathrm{EMBRAPA}^{2}, \mathrm{MAPA}^{3}$, etc), o agronegócio e a sociedade.

O interesse pelo assunto veio com o "Chamamento Público - Pesquisadores e Ecossistema de Inovação no Combate ao Covid19", do Governo do Maranhão. Tal evento gerou um estudo de Souza ${ }^{4}$ (2020), enviado em 4 abr. à Secretaria de Ciência, Tecnologia e Inovação (SCTI) do referido Estado, e apresentado na $17^{\text {a }}$ Semana Nacional de Ciência e Tecnologia no Maranhão, de 19 a 23 out. 2020.

A pesquisa bibliográfica encontrou citações esparsas sobre as referidas barreiras em artigos, dissertações, teses e livros. Nesses estudos percebeu-se certa confusão quando consideraram como se fossem a mesma estrutura, o rodolúvio e o arco de desinfecção. Tal equívoco será esclarecido mais adiante. No momento, o que há é o referido estudo de Souza (2020), onde percebeu-se que o silêncio acadêmico sobre o tema parece repercutir na carência de legislações, na timidez da indústria em produzir arcos de desinfecção e na falta de políticas públicas de Estado para adoção preventiva de tais equipamentos em todo o país, para combater o novo coronavírus.

\footnotetext{
${ }^{1}$ Agência Estadual de Defesa Agropecuária.

${ }^{2}$ Empresa Brasileira de Pesquisa Agropecuária.

${ }^{3}$ Ministério da Agricultura, Pecuária e Abastecimento. Conforme será visto na Seção III, a sigla do Ministério nas legislações emitidas pelo órgão, costuma ser alterada de acordo com o governo (Port n ${ }^{\circ} 711$-MAARA, de $1^{\circ}$ nov 1995 ; IN n ${ }^{\circ} 04-$ MAA, de 30 dez 1998, etc.).

${ }^{4}$ Estudo feito de modo voluntário. No momento o autor não tem vínculo com instituição de pesquisa.
} 
O estado da arte revela algo que parece uma tabula rasa (BLACKBURN, 1997), uma tábua sem inscrições, uma folha de papel em branco. Por isso, o assunto precisa ser melhor investigado pelos pesquisadores ligados às Ciências Agrárias, ao agronegócio.

Pretende-se trazer à tona o tema e ajudar para que outros, mais habilitados, avancem na pesquisa. Isso poderá contribuir com o desenvolvimento rural, com as Ciências Agrárias, com a sociedade e com o meio ambiente. Produzir estudos sobre tais estruturas será, de certo modo, um ajuste de contas com a História.

O trabalho é composto, além desta introdução, pelas seções: Possível etimologia dos termos "pedilúvio" e "rodolúvio"; As barreiras sanitárias e o aspecto legal; Consequências da escassez de estudos científicos; e Considerações Finais.

\section{POSSÍVEL ETIMOLOGIA DOS TERMOS “PEDILÚVIO” E “RODOLÚVIO”}

O dicionário Priberam Online não registra o termo rodolúvio, mas exibe, conforme seu site, o vocábulo pedilúvio com as seguintes definições: "1. Banho dado aos pés ou às patas. 2. Local destinado a lavar os pés ou as patas" (PEDILÚVIO, 2008, grifos nossos). Assim, parece admitir a existência de relação entre o termo e o meio rural ou com as Ciências Agrárias, mas não dá exemplos.

Ferreira (2010, p. 1591) diz, também sem dar exemplos, que pedilúvio é o "banho dos pés"; e que luvio vem do latim luere, e significa lavar à maneira de dilúvio, ou seja, com muita água. Exemplos foram encontrados em duas obras da literatura nacional: $1^{a}$ ) em "A Moreninha" (MACEDO, 2013), onde o vocábulo aparece quatro ${ }^{5}$ vezes, nos seguintes trechos: a) no sumário; b) no título do cap. XIV, "Pedilúvio Sentimental"; c) em "[...], a bacia em que Paula deveria tomar o pedilúvio;" (p. 126); e d) em "Veja se eu sei dar um pedilúvio!" (p. 127, grifos nossos); e 2a) em “Oração aos moços" (BARBOSA, 1999), quando, ao falar dos seus estudos, o autor negou o uso de artifícios para ficar acordado na madrugada. Assim ele disse: "Refratário sou ao café. [...]. Nem uma só vez na minha vida busquei num pedilúvio o espantalho do sono” (p. 31, grifo nosso).

Como se vê, o significado de pedilúvio em Ferreira (2010) e aquele usado como calmante ou excitante, nos exemplos da literatura brasileira, não têm relação com a definição do Priberam. Então, a palavra não veio do meio rural, mas parece ter sido tomada de "empréstimo".

A pesquisa mostrou que os dois termos não são criações acadêmicas, embora citados em vários estudos. Como não foi possível saber da academia, onde, como e quando tais palavras surgiram no

\footnotetext{
${ }^{5} \mathrm{Na}$ edição de 2011 da Martin Claret, falta a quarta citação de pedilúvio, a qual se encontra na frase "Veja se eu sei dar um pedilúvio!", que está na última página do capítulo XIV. O leitor atento e conhecedor do romance poderá perceber o equívoco que resultou num texto truncado, porque incompleto. Por esse motivo trocou-se a editora e a edição da obra. 
meio rural, acredita-se que a Instituição se mantenha alheia à necessidade do real conhecimento do tema. Buscou-se apoio no senso comum rural e recorreu-se à categoria sociológica "memória" (Blackburn, 1997), a despeito dos problemas que isso possa suscitar - de fazendeiros e peões idosos, mas eles nada souberam dizer. Nessas condições, criou-se a hipótese de que o termo pedilúvio foi tomado de "empréstimo" da literatura em algum momento da vida rural, nos idos de 1960, e o neologismo rodolúvio, não encontrado nos principais dicionários de português no Brasil, veio depois.

Reis (1955), numa obra densa, indicou que, até aquele ano, o termo pedilúvio não existia na fala do homem rural e nem na academia. Isso está explícito em seu livro quando, no capítulo "Limpeza e desinfecção", com dez páginas, em nenhum momento a referida palavra aparece. $\mathrm{Na}$ densidade de sua obra ele definiu previamente o que chamaram de pedilúvio, da seguinte forma: "Percebe-se, pois, a vantagem de colocar à porta de cada cercado um reservatório raso com um desinfetante adequado, como por exemplo a cal, no qual os visitantes ou tratadores deverão pisar antes de entrar nos galinheiros (p. 77, grifo nosso). Talvez ele não tenha visto relação entre seu reservatório raso e a definição de pedilúvio daquela época, porque, na verdade, não havia relação. A fim de ilustrar a ideia de Reis (1955), fez-se a figura abaixo.

Figura 01: Simulação do recipiente raso, de Reis (1955), colocado na entrada dos cercados.

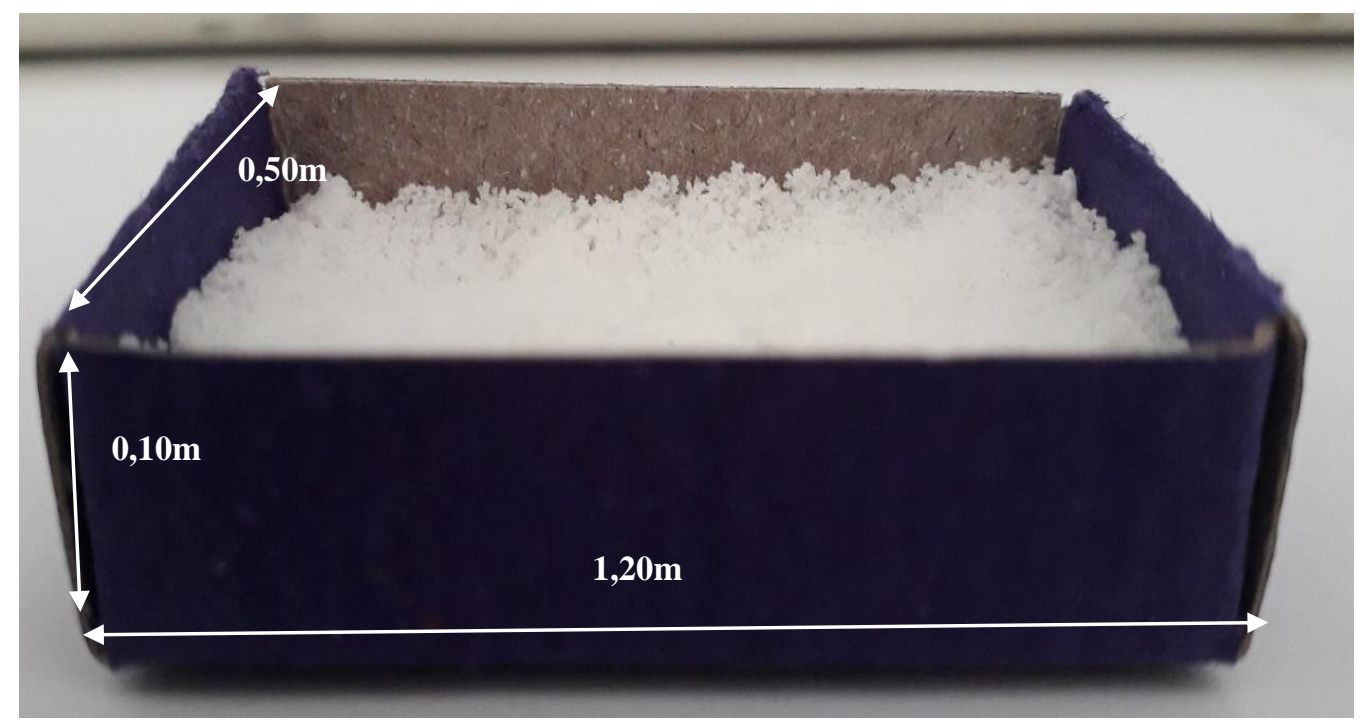

Fonte: foto ilustrativa feita em 2020 pelo autor, para este artigo, a partir de uma caixa de fósforo.

Em Reis (1955), o recipiente não tinha água, mas apenas cal; e também não tinha a finalidade de desinfetar os cascos dos animais. Tais fatos foram determinantes para que ele descartasse qualquer relação entre sua estrutura e o pedilúvio usado pela sociedade de então, constante das obras literárias. Mas, em razão do devir, surgiria uma relação, e o "empréstimo" da palavra pelo meio rural seria só uma questão de tempo. Admitamos que foi isso que aconteceu. 
Acredita-se, à luz de Lyra e Silva (2004), que isso ocorreu no início da epidemia da febre aftosa no Brasil, que perdurou entre 1960 e 2002. Talvez um pouco antes, pois não se encontrou registro do fato. O "empréstimo" foi algo sem importância na rotineira vida rural, onde não é comum a preocupação com a língua culta ou com o surgimento de palavras.

Onde foram descobertas as duas barreiras? Foi ao mesmo tempo e no mesmo lugar? Não foi possível encontrar o local onde foram descobertas, mas, à luz da história, acredita-se que não surgiram ao mesmo tempo. É certo que, devido ao período de ocorrência da febre aftosa (entre 1960 e 2002), o termo pedilúvio veio antes do neologismo rodolúvio. Tal hipótese é reforçada pelo autor abaixo, que ao falar sobre as condições das estradas em 1970, diz:

As estradas existentes, e parcamente sinalizadas, davam conta de atender aos interesses da mais expressiva atividade econômica da região, que era a pecuária extensiva. Para o transporte das tropas de gado as estradas eram aceitáveis. Já para o tráfego de caminhões essas mesmas vias eram totalmente inadequadas, pois as estradas praticamente eram uma continuação dos campos e matos, quando não dos próprios leitos dos rios e lagos. Muitas das pontes existentes, pois em vários trechos das estradas elas não existiam, ou a situação destas já estava muito precária, ficavam avariadas com a passagem de veículos pesados, ainda mais quando estes transportavam mercadorias ou grãos, como a soja. (MORO, 2012, p. 154, grifo nosso).

Em Moro (2012) percebe-se que na década de 1970, as estradas eram usadas para deslocamentos a pé das tropas de gado. Os rebanhos eram conduzidos por peões a cavalo porque as estradas não permitiam o tráfego de caminhões e os veículos daquela época, ao que parece, ainda não tinham carroçarias para o transporte do gado.

O problema das estradas persiste ainda hoje em vários rincões do país, principalmente nas regiões Norte e Nordeste, onde há rodovias com longos trechos de estradas de chão. Segundo Curado (2019), é no Nordeste, na cidade de Cabedelo/PB, que tem início a terceira maior rodovia do país, a Transamazônica. Sua construção, iniciada em 1972, no governo Médice, segue inacabada. Com seus 4.260 km, passa por sete estados: Paraíba, Ceará, Piauí, Maranhão, Tocantins, Pará e chega à cidade de Lábrea, no Amazonas.

Desse modo, tais fatos reforçam a hipótese de que o "empréstimo" do termo pedilúvio ocorreu antes do surgimento do neologismo rodolúvio, que permanece fora dos dicionários. Essa antecedência do pedilúvio foi, em grande parte, devido à epidemia da febre aftosa que se espalhava pelo país e que exigia um modo mais rápido de desinfetar os animais. Antes da aftosa, os cascos dos animais eram desinfetados com uma espécie de pincel (ou esponja) molhado no desinfetante. Era um trabalho demorado e, na epidemia, a corrida era contra o tempo, tal como ocorre na atualidade com a pandemia do novo coronavírus. Os animais, ou seus cascos, precisavam ser desinfetados de modo rápido. 
Em Reis (1955), o recipiente raso e sem água, construído sem aval científico, veio para substituir o pincel até então usado na desinfecção. A pesquisa indica que o termo pedilúvio e seu “empréstimo" foram frutos do trabalho diário e da exigência de agilizar o serviço. Algo que veio do senso comum, da criatividade da vida rural, sem tecnologia e com um quê popular.

É provável que esse fato, aliado à carência de estudos, justifique a sucinta definição de pedilúvio em Ferreira (2010) e sua ausência em outros dicionários da língua portuguesa no Brasil. Esse mesmo autor, como se desconfiasse de algo, nada diz sobre o "empréstimo" da palavra pelo meio rural ou por quaisquer das Ciências Agrárias. E por que não diz nada? Porque a academia costuma desconfiar daquilo que não é feito por especialista ou daquilo que é popular. No primeiro caso, um exemplo é a história ${ }^{6}$ da apresentação do curriculum de James Murray, filólogo autodidata, ao Museu Britânico em 1867, que o recusou (WINCHESTER, 2009, p. 44-45). No segundo caso, sobre o significado de pedilúvio, no Priberam Online, chama-se atenção, mais uma vez, porque é nele que se faz relação do vocábulo com o meio rural. Isso pode ter ocorrido devido ao fenômeno que, na transcrição abaixo, é chamado de falsa etimologia.

Etimologia. 1. O estudo das palavras, de sua história e das possíveis mudanças de seu significado. 2. Origem e evolução histórica de um vocábulo. Por exemplo: a etimologia do vocábulo português malha pode ser reconstruída até chegar-se ao latim macula. Etimologia popular. Atribuição de falso étimo a um vocábulo, em razão de alguma semelhança com um outro; falsa etimologia. Por exemplo: forró, segundo etimologia popular, viria do inglês for all, 'para todos' (FERREIRA, 2010, p. 887).

Nessa citação, a definição de falsa etimologia parece reforçada quando se consideram os dados: 1) segundo Lyra e Silva (2004), a febre aftosa acabou no país em 2001; e 2) o registro do termo pedilúvio no Priberam, segundo o site, foi em 2008, ou seja, 07 anos após o fim da referida epidemia. Assim, entre 1960 (considerado aqui como o ano do "empréstimo" do termo pedilúvio) e 2010 (edição do Aurélio), tem-se aí 50 anos de uso do referido termo no meio rural e de breves citações em estudos acadêmicos e em legislações, conforme será visto na próxima sessão, nas três esferas da Administração Pública. Tais fatos podem ter induzido a dicionarização no Priberam.

A despeito de tudo isso, Ferreira (2010), com suas 2272 páginas, e que representa a consolidação de sua produção nessa área, não seguiu o Priberam e manteve-se em silêncio. Não fez relação entre o termo pedilúvio e o meio rural ou com as Ciências Agrárias. Ao agir assim, emudecido, tal autor parece ter ensinado mais uma vez, como não usar um vocábulo. Seu silêncio é entendido quando se lê, na Apresentação de sua obra, o modo como ele ensinava. Ali se diz: "Ensinava o

\footnotetext{
${ }^{6}$ Sugere-se o filme "O gênio e o louco" (2019), dirigido por Farhad Safinia, inspirado na obra "O professor e o louco", de Simon Winchester, estrelado por Mel Gibson (que interpreta o filólogo autodidata James Murray) e Sean Penn (que interpreta o médico William Chester Minor).
} 
significado das palavras e, mais, ensinava como as usar e, até mesmo, como não usá-las. E é assim até hoje. Seu legado permanece vivo na obra que aqui é apresentada, o Dicionário Aurélio, ou simplesmente Aurélio [...]”.

O Priberam registrou o termo pedilúvio, mas não rodolúvio. Apesar da possível influência da falsa etimologia, se isso não tivesse acontecido, talvez o vocábulo não tivesse sido dicionarizado. E se não fosse assim, talvez tivesse o mesmo destino que o termo rodolúvio, ou seja, teria "caído" no esquecimento ou num certo "limbo" das coisas inúteis. Mas aquelas duas palavras, pelo pouco que se conseguiu de suas histórias com o meio rural, é possível afirmar que nunca foram inúteis. Nem as palavras, nem as estruturas que representam, as quais foram, são e ainda serão úteis à sociedade por longos anos.

Ferreira (2010) agiu de modo semelhante ao Priberam: registrou o termo pedilúvio, mas não o rodolúvio. Para saber sobre a inserção do termo naquela obra e se rodolúvio estará na próxima edição do Aurélio, enviou-se e-mail à editora ${ }^{7}$, da qual veio a resposta abaixo.

Prezado Sr. Ivanilson. [...]. Vamos ficar lhe devendo a data de inserção do verbete "pedilúvio". Ocorre que a nossa base de dados dos dicionários (onde consta essa informação) não está disponível remotamente, então, como a equipe da Editora está em home office, verificar essa informação não será possível por ora, mas nos comprometemos que, ao voltar do isolamento, lhe enviamos essa informação. Sobre a inserção do termo "rodolúvio", não podemos lhe precisar, pois ainda estamos projetando a nova edição da obra. Ficamos à disposição. Cordialmente. Central de Atendimento - Dicionários. Positivo Soluções Didáticas (sic.).

A explicação da Editora Positivo deveu-se ao isolamento social em razão do novo coronavírus.

Ao falar sobre a etimologia popular, Ferreira (2010) fortaleceu a hipótese do "empréstimo" pela área rural. Pedilúvio não é um termo do linguajar caboclo; não é algo do interior do país, como se pensou no início. Dado sua presença na literatura brasileira, é provável que tenha sido importada, embora não tenha sido encontrada nos idiomas espanhol e inglês.

A hipótese ganhou força quando ouviu-se um empresário paulista, de 65 anos de idade, com estreita ligação com o agronegócio, conhecedor de vários causos do meio rural e também detentor de informações científicas de sua própria área de formação. Engenheiro elétrico pela USP, ele tem colaborado com a produção, a inovação e a venda de equipamentos agrícolas que têm beneficiado a produção rural em todo o país. Ao ouvir nossa hipótese ele fez o relato ${ }^{8}$ abaixo:

Isso faz sentido. É possível que essas palavras tenham surgido exatamente assim, como "gírias" do setor agrícola. O brasileiro tem mania de facilitar tudo. Até 1970 a

\footnotetext{
${ }^{7}$ Direitos cedidos com exclusividade para a Língua Portuguesa em todo o mundo para a Editora Positivo. [...] (FERREIRA, 2010, p. 4).

${ }^{8}$ Conversa, em 11 jun. 2020, por telefone, das $09 \mathrm{~h}$ às 10:40h.
} 
desinfecção dos cascos dos animais era feita com um pincel molhado no desinfetante. Imagina fazer isso em muitos animais. Aí tiveram a boa ideia de fazer o "pé-delúvio" (em associação ao dilúvio bíblico) e deram esse nome ao tanque raso. Mais tarde, com o aumento da produção começaram usar veículos para transportar os animais e aí tiveram ideia semelhante e criaram o "rodo-lúvio", com área suficiente para que o veículo pudesse entrar, molhar todas as rodas e deslocar-se lentamente de modo que ocorresse a "desinfecção". A diferença básica entre os dois é que o pedilúvio destina-se a desinfetar os animais que estão com algum problema nos cascos e o rodolúvio destina-se a desinfetar as rodas de todo veículo que entrar no criadouro.

O que aquele empresário chama de "gírias" do setor agrícola, parece equivaler ao fenômeno que Ferreira (2010) chama de etimologia popular. Nesse sentido, dá a impressão de reforçar a possibilidade do Priberam Online ter sido influenciado pelo fenômeno da falsa etimologia. Assim, Reis (1955) e Ferreira (2010) escaparam dessa enganação porque não relacionaram o pedilúvio, da literatura, com o recipiente raso usado no meio rural.

O Glossário de Termos Agropecuários do BNDES (GTA/BNDES) repetiu o equívoco do Priberam e revelou não ter se aprofundado no tema quando disse:

Pedilúvio9 - tanque raso que contém água ou substâncias terapêuticas e/ou curativas, geralmente construído na entrada ou na saída dos currais e salas de ordenha com o objetivo de efetuar a higiene e/ou tratamento dos cascos dos animais; pode ser usado em aeroportos, estradas e outros locais em caso de doenças provocadas por agentes patógenos que podem ser carregados nos pés e patas de animais; o tanque utilizado para a desinfecção de veículos recebe o nome de rodolúvio $(2012$, p. 8, grifo nosso).

Tal definição, equivocada e anacrônica, indica que o termo vem do meio rural, mas não foi isso que este estudo encontrou. O GTA/BNDES teria corrigido o equívoco se alertasse: "vocábulo emprestado pelo meio rural, onde passou a ser relacionado ao recipiente raso de desinfecção de cascos/patas de animais”. Ao falar do rodolúvio, deixou transparecer que há, entre as duas barreiras, uma proximidade que não existiu. Devido à ineficiência dessa estrutura, seu uso é cada vez menor no país, onde tem sido substituído pelo arco de desinfecção. Não foram encontradas as etimologias das duas barreiras, mas isso não diminui a importância que tiveram, sendo que a primeira foi mais efetiva na epidemia da aftosa e que, após aperfeiçoamentos, segue em pleno uso, ao contrário da segunda.

Não foi possível saber onde e quando esse tipo de barreira foi usado pela primeira vez. Fezse contato com as Agências de Defesa Sanitária da Bahia, Maranhão, Minas Gerais, Rio Grande do Sul, Santa Catarina e São Paulo, e com o MAPA, mas a única resposta oficial veio da AGED/MA, no Despacho no 068-2020-CDA/AGED-MA, de 07 ago. 2020, transcrito abaixo.

\footnotetext{
${ }^{9}$ Zootecnia: Glossário de Termos Agropecuários do BNDES. Disponível em: <https://aincetooz.blogspot.com/2012/03/ glossario-de-termos-agropecuarios-do.html>. Acesso em 20 maio 2020.
} 
Em resposta a solicitação encaminhada por meio do NUP 65441.000032/2020-13, informamos que conforme despacho proferido pelo Setor de Trânsito Animal, responsável pelos Postos Fixos de Fiscalização Agropecuária, Fiscalizações Móveis e Volantes Agropecuárias, não possuímos bibliotecas ou bibliografias nacionais ou estrangeiras sobre barreiras sanitárias (Grifo nosso).

Vale esclarecer, que todos os procedimentos referentes a implantação de barreiras sanitárias, bem como a utilização de rodolúvio, pedilúvio e arco de desinfecção, são realizadas seguindo as orientações contidas nos Manuais do Ministério da Agricultura, Pecuária e Abastecimento (MAPA), dependendo da enfermidade envolvida e das medidas preventivas e de desinfecção determinadas pelos Programas Sanitários. [...]. (sic.)

Essa resposta da AGED/MA parece explicar as dificuldades em obter informações, assim como não restam dúvidas da falta de bibliografias sobre o tema no país, sejam elas nacionais ou estrangeiras. Então, sugere-se cessar - como forma de acertar as contas com a História, com a língua portuguesa e com as Ciências Agrárias -, a partir de agora, os equívocos acerca do "empréstimo" do termo 'pedilúvio' para designar o recipiente raso de Reis (1955). E num reconhecimento tardio pela obra desse autor, sugere-se que a referida estrutura passe a ser chamada de Recipiente Raso com Desinfetante Adequado (RRDA/1955) ou apenas REIS1955.

No caso do neologismo rodolúvio, sugere-se deixar que a Editora Positivo, responsável pelo dicionário Aurélio, faça seu registro com a respectiva definição. Assim o vocábulo entrará para a História num momento em que já quase saiu do mundo ou deixou de existir no Brasil.

\section{AS BARREIRAS SANITÁRIAS E O ASPECTO LEGAL}

O novo coronavírus forçou a população mundial a rever uma série de hábitos e adotar outros, como o uso de barreiras sanitárias. Tal expressão é vista na imprensa, na boca do povo e, fisicamente, nas pessoas, como luvas, máscaras, etc. Souza (2020, p. 16) ao pesquisar sobre a legalidade das barreiras sanitárias diz que:

[...] apesar de inexistir nas referidas legislações a expressão "barreira sanitária", isso é insuficiente para dizer-se que esse tipo de barreira não é um instrumento legal. Sua adoção pode ser amparada pela discricionariedade do gestor ou por legislações internas de cada órgão, dentre as quais destacam-se, Normas Técnicas, Portarias, Regulamentos, etc. Frisa-se que não foi possível ter acesso a tais legislações.

Souza (2020) não teve acesso às legislações internas do Poder Público e não descartou a possibilidade da expressão "barreira sanitária" ser definida em alguma delas. Mas isso não será tratado neste artigo. O que se vê é que o tempo não reduziu o uso das barreiras, mas ampliou e as aperfeiçoou, ao adicionar água no recipiente raso, conforme a figura 02. 
Figura 02: Detalhe de pedilúvio para bovinos. Estrutura em ferro.

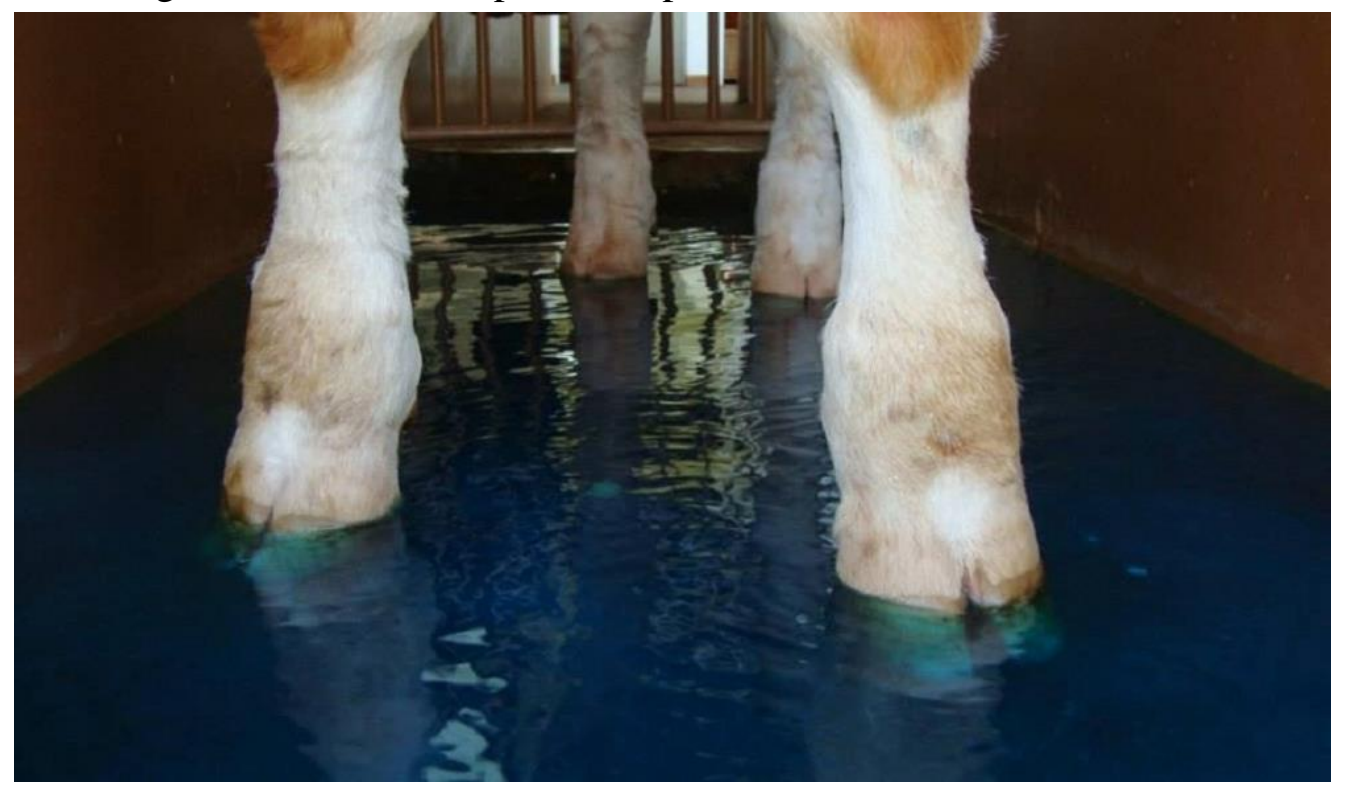

Disponível em: <http://www.coagril-rs.com.br/upload/informativos_87_1146_1497462162.jpg>. Acesso em 20 jul. 20.

Na figura 02 acima, vê-se que o fato do recipiente ser raso permite que a solução desinfetante tenha um maior contato com os cascos. Tal fato parece mostrar um segundo equívoco na definição do Priberam, quando ele diz que a desinfecção é dos cascos e das patas.

Por outro lado, o rodolúvio quase desapareceu, mas ainda é visto em certas propriedades do interior do país, em geral, nos rincões mais afastados e de menor poder econômico. Sem necessidade de maiores explicações, observa-se facilmente, na figura 03 a seguir, que sua ineficácia e ineficiência decorrem de aspectos como sua localização em área aberta e descoberta. Tal fato deixa a estrutura exposta às intempéries e isso diminui o tempo de validade da solução desinfetante. Em razão de sua obsolescência, não há que se falar em legislação.

Figura 03: Rodolúvio original, na entrada de uma propriedade.

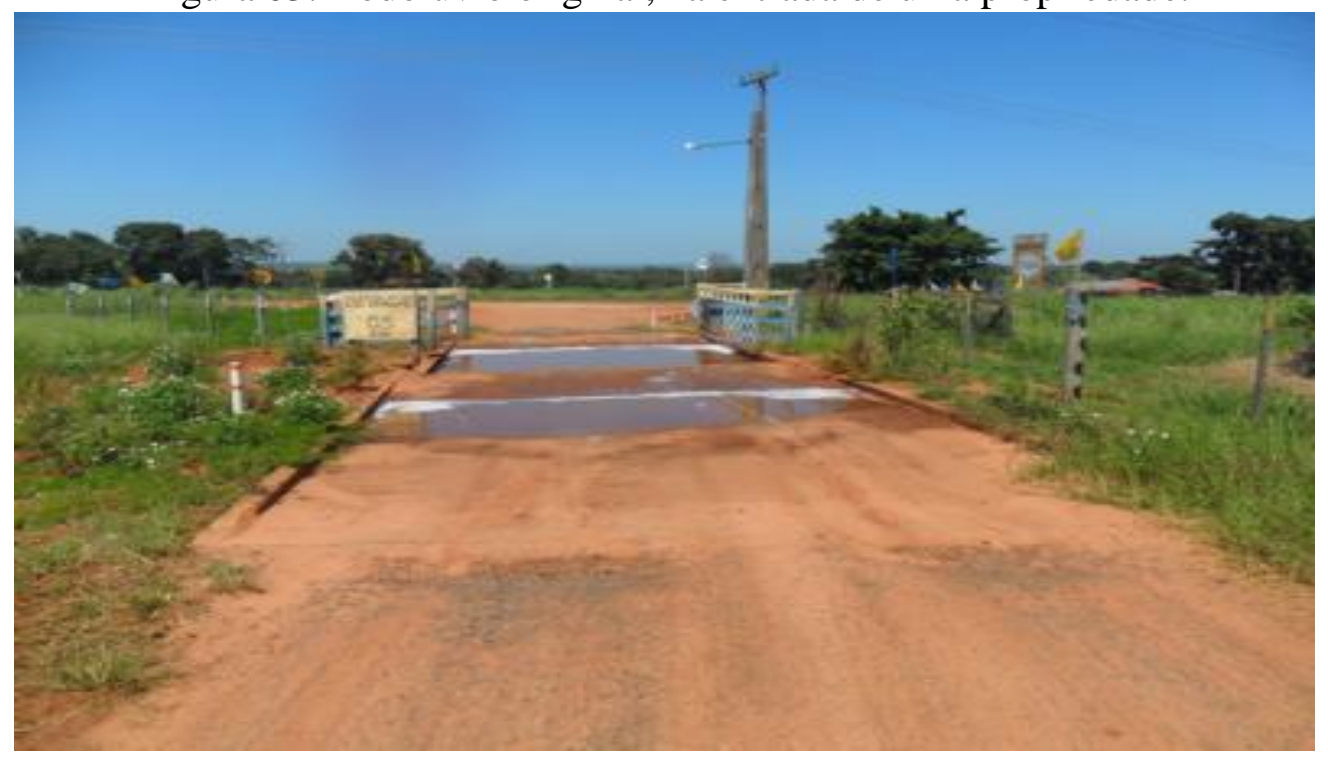

Fonte: (SOUZA, 2020). 
Se os gestores observassem a legislação, tal barreira não existiria nos órgãos públicos devido aos riscos para o meio ambiente e em razão de sua ineficiência. A CF/1988 alerta, no inciso VI do Artigo 23, sobre o cuidado com o meio ambiente, e no caput do Artigo 37, onde elenca, entre outros, o princípio da eficiência, pelo qual a Administração deve primar. Por isso, os aperfeiçoamentos do arco de desinfecção, aos poucos, têm eliminado a semelhança com o rodolúvio. Os atuais modelos dão especial atenção à redução do consumo de água. Assim, no ato da desinfecção, uma nuvem de micro gotículas, que mais parece vapor, é produzida sob alta pressão e aplicada sobre os veículos, conforme a figura abaixo

Figura 04: Arco de desinfecção em funcionamento. Esse tem altura fixa.

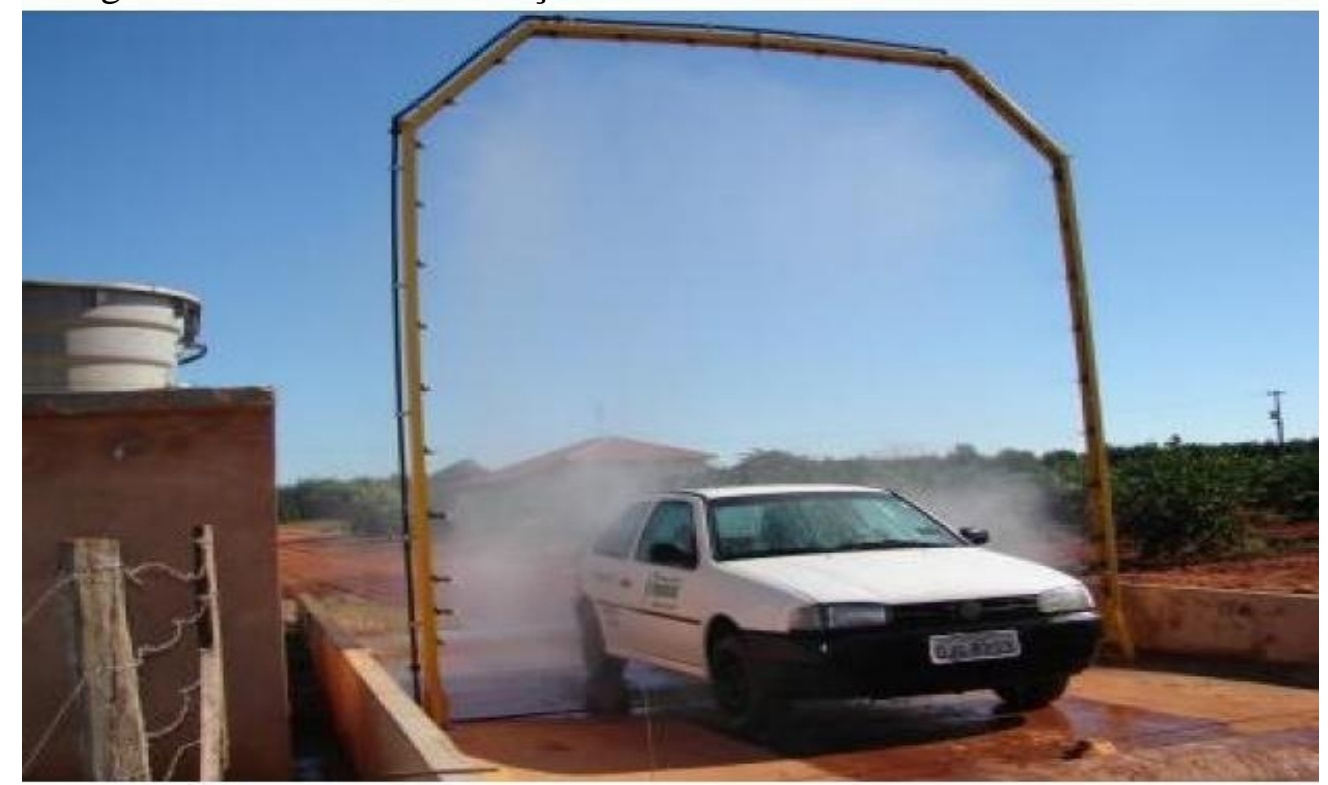

Fonte: (SOUZA, 2020)

À semelhança do que tem ocorrido nos estudos acadêmicos, diversos órgãos públicos, nas três esferas da Administração, têm mencionado, também de modo conciso, as barreiras sanitárias. A esse respeito elaborou-se a tabela abaixo, com as principais normas encontradas e que, de um modo ou de outro, mencionaram as barreiras sanitárias discutidas neste artigo. Chama-se atenção para o período dessas normas, que varia de 1995 a 2020, ano em que o Governo Federal elaborou a Lei no 13.979, de 06 fev., específica sobre recursos para combater a pandemia do novo coronavírus. Ressalta-se que essa lei nada diz sobre as três barreiras. 
Tabela: Legislação com o n ${ }^{\circ}$ de citações dos termos pedilúvio, rodolúvio e arco de desinfecção.

\begin{tabular}{|c|c|c|c|}
\hline \multirow[t]{2}{*}{ Legislação } & \multicolumn{3}{|c|}{$\mathrm{N}^{0}$ de citações } \\
\hline & Pedilúvio & Rodolúvio & Arco \\
\hline $\begin{array}{l}\text { Port } \mathrm{n}^{\mathrm{o}} 711 \text {, de } 1^{\circ} \text { nov. } 1995 \text {, do Ministério da Agricultura, do } \\
\text { Abastecimento e da Reforma Agrária (MAARA) }\end{array}$ & 03 & 0 & 0 \\
\hline $\begin{array}{l}\text { Res n. }{ }^{\circ} \text { 18-SAA, de } 31 \text { mar. 1998, da Secretaria Estadual de } \\
\text { Agricultura e Abastecimento/SP }\end{array}$ & 01 & 01 & 0 \\
\hline $\begin{array}{l}\text { Instrução Normativa (IN) no 04-MAA, de } 30 \text { dez. 1998, do } \\
\text { então Ministério da Agricultura e do Abastecimento }\end{array}$ & 0 & 01 & 0 \\
\hline $\begin{array}{l}\text { Port } n^{\circ} 114-A D A B \text { de } 7 \text { jul. 2002, da Bahia - Manual Técnico- } \\
\text { Sanitário (MTS) }\end{array}$ & 02 & 04 & 0 \\
\hline IN no 60 -MAPA de 6 nov. 2002 - Anexo II & 01 & 01 & 0 \\
\hline $\begin{array}{l}\text { IN no } 31 \text {-MAPA, de } 9 \text { jun. 2011, Manual de Procedimentos de } \\
\text { Defesa Agropecuária }\end{array}$ & 02 & 02 & 0 \\
\hline $\begin{array}{l}\text { Port n }{ }^{\circ} 1.217-I M A \text {, de } 30 \text { maio 2012, do Instituto Mineiro de } \\
\text { Agropecuária }\end{array}$ & 01 & 01 & 0 \\
\hline $\begin{array}{l}\text { Dec Est } \mathrm{n}^{\circ} 50.072 / \mathrm{RS} \text {, de } 18 \text { fev. } 2013 \text { - regulamentou a Lei } \\
\mathrm{n}^{\mathrm{o}} 13.467 \text { de } 15 \text { jun. } 2010 \text {, do Rio Grande do Sul }\end{array}$ & 01 & 01 & 0 \\
\hline Port $\mathrm{n}^{\mathrm{o}}$ 1.391-IMA de 06 jan. 2014 & 01 & 01 & 0 \\
\hline Port $\mathrm{n}^{\circ} 3.524-\mathrm{IAGRO}$, de $1^{\circ} \mathrm{dez} .2015$, do Mato Grosso do Sul & 01 & 01 & 0 \\
\hline NT $n^{\circ} 1$, de $1^{\circ}$ jun. 2017, da Secretaria de Saúde/Recife & 01 & 0 & 0 \\
\hline Lei $n^{\circ}$ 13.979, de 06 fev. 2020, do Congresso Nacional & 0 & 0 & 0 \\
\hline
\end{tabular}

Fonte: pesquisa em sites na internet (2020) para este artigo

Na tabela acima, apenas a IN no 4-MAA, o Dec $n^{\circ}$ 50.072/RS e a Port $n^{\circ} 3.524-I A G R O ~ c i t a m$ um sistema equivalente ao rodolúvio, mas não dizem se é o arco de desinfecção. Ressalta-se que há empresas que produzem e vendem arcos há mais ou menos trinta anos. Souza (2020) destaca as seguintes: Fornari Indústria, de Concórdia/SC; Alma Equipamentos para Pulverização Ltda, de Araras/SP e a Herbicat Produtividade Sustentável, de Catanduva/SP.

Nas normas estudadas viu-se o Poder Público sem informações sobre o que legislar. Assim, tem citado brevemente as barreiras e, às vezes, feito confusão, como a ocorrida em 25 ago. 2015, na Câmara dos Deputados, na audiência pública da Comissão de Agricultura, Pecuária, Abastecimento e Desenvolvimento Rural ${ }^{10}$. Ali, ao tratar sobre alterações das IN n 56/2007 e 59/2009, o deputado Heitor Schuch (PSB/RS) disse:

\footnotetext{
${ }^{10}$ Ver matéria intitulada “Comissão discute medidas para o setor de avicultura do Rio Grande do Sul”, disponível em: <http://www.psbnacamara.org.br/not_det.asp?det=4680>. Acesso em 14 maio 2020.
} 
Colocaremos pedilúvio, rodolúvio, entre outras barreiras naturais que já existem, como árvores que sirvam de quebra vento e faremos, também, o rastreamento das aves migratórias que transportam vírus, para que possamos continuar a produzir, exportar e manter essas pessoas no campo, gerando emprego,... (Grifo nosso).

O deputado pareceu confundir-se ao equiparar pedilúvio e rodolúvio a barreiras naturais. Esse é outro equívoco que pode ser explicado pela escassez de estudos.

Com a pandemia do novo coronavírus, uma indústria de Santa Catarina lançou no mercado uma barreira nova, o túnel de desinfecção de pessoas, semelhante ao da figura 05, abaixo. Eis aí uma "via de mão dupla" e "sem sinalização" (os estudos). Isso abriu uma disputa entre a indústria e o Poder Público Estadual, que proibiu o comércio da referida barreira em seu território. Enquanto uma investe e produz, o outro proíbe o comércio do que é produzido. Nesse caso, ambos agiram sem a orientação proveniente de estudos adequados.

\section{Figura 05: Túnel de desinfecção de pessoas, em loja de São Luís-MA.}

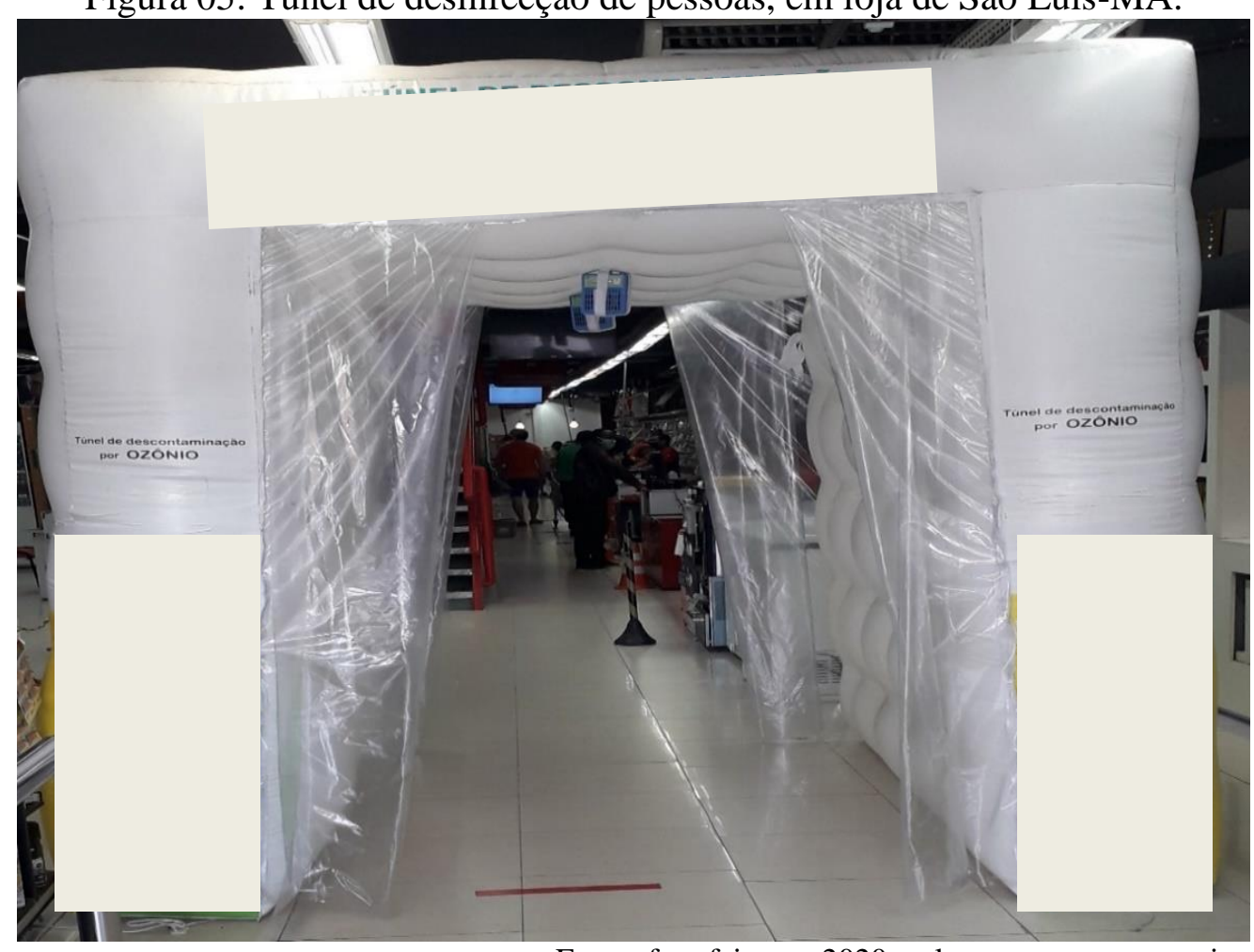

Fonte: foto feita em 2020, pelo autor, para este artigo.

A Port. no 312-SES, de 12 de maio de 2020, da Secretaria Estadual de Saúde/SC, sobre medidas de prevenção para o funcionamento dos estabelecimentos de frigoríficos de carnes, menciona no artigo 20, inciso IX: "Fica proibido o uso de sistemas de desinfecção por meio de um túnel onde são pulverizados produtos desinfetantes diretamente sobre as pessoas". O que se vê nessa norma é que o Poder Público de Santa Catarina faz breve citação e isso parece revelar, mais uma vez, a falta de 
estudos sobre o tema. A referida barreira, proibida num Estado, foi exportada para outros e segue sendo comercializada, como em São Luís, conforme a Figura 05 acima.

\section{CONSEQUENCIAS DA ESCASSEZ DE ESTUDOS CIENTÍFICOS SOBRE O TEMA}

A ciência tem entre seus papéis o de solucionar problemas da sociedade. Há séculos tem sido assim, tanto para o bem como para o mal. Segundo Cardoso (2017), a ciência que produz inseticidas é a mesma que produz armas químicas e biológicas ${ }^{11}$. Muito daquilo que as pessoas usam, sabem ou fazem, foi descoberto por cientistas e pesquisadores nas diversas áreas do conhecimento.

A barreira sanitária aqui proposta para desinfetar veículos e ajudar combater o novo coronavírus ainda não foi experimentada na academia. Sobre a experimentação, o autor abaixo diz:

Todavia, foi o Renascimento que elevou a experimentação ao nível de um princípio da pesquisa como tal. Sem dúvida nenhuma, os precursores foram os grandes inovadores no domínio da arte: Leonardo da Vinci e seus companheiros e, particularmente e de maneira característica no domínio da música, aqueles que se dedicaram à experimentação com o cravo, no século XVI. Depois disso, a experimentação passou para o campo das ciências, por causa, principalmente, de Galileu e alcançou o domínio da teoria, graças a Bacon. A seguir, foi perfilhada pelas diferentes universidades do continente europeu, no início e principalmente pelas da Itália e da Holanda, estendendo-se ao domínio das ciências exatas. (WEBER, 2003).

Tal citação evidencia as questões: por que as barreiras não foram experimentadas? Quais as consequências da falta de estudos sobre elas? Como saber se desinfetam? O poder público controla a qualidade das estruturas produzidas e comercializadas no país?

À primeira questão, acredita-se que não foram experimentadas porque nada foi achado a esse respeito. E a experimentação, segundo Weber (2003) é uma das etapas da ciência. Talvez não tenham sido porque surgiram fora dos muros da academia. $\mathrm{O}$ arco de desinfecção, apesar de sua estrutura engenhosa, não é obra da engenharia científica. Mas isso não impede que tenham razoável grau de automatização, como aqueles da figura 04 e da figura 06, abaixo.

\footnotetext{
${ }^{11}$ Armas químicas e biológicas: a mesma ciência que inventou os inseticidas produz uma praga terrível: as armas químicas. Disponível em: <https://super.abril.com.br/ciencia/armas-quimicas-e-biologicas/>. Acesso em 14 ago. 2020.
} 
Figura 06: Veículo passando sob arco de desinfecção automatizado.

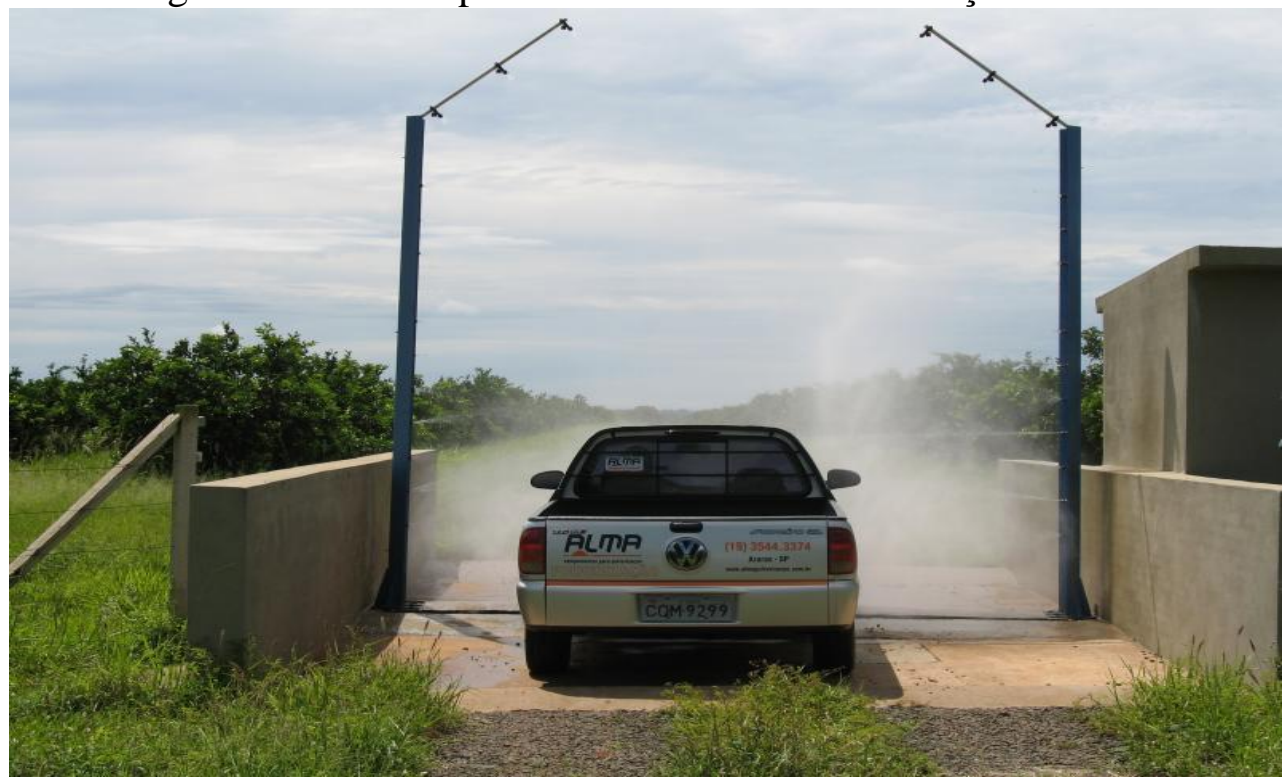

Fonte: Disponível em: <https://bitlybr.com/ybpyJ>. Acesso em 20 maio 2020

A segunda questão é óbvia e já foi respondida: se não há estudos, ou se são superficiais, o resultado é essa dificuldade de saber onde e quando tais barreiras foram usadas pela primeira vez no país; breves menções no texto legal; órgãos públicos com poucas ou sem informações; inexistência de legislações específicas; etc.

Em matéria jornalística do programa Globo Rural, de 28 jun., sobre o desaparecimento das abelhas no oeste do Pará, a promotora Ione Nakamura, do MPE/PA, ressaltou, dentre outros aspectos, a importância das pesquisas como subsídio para as ações do Poder Público. Ela disse:

O monitoramento social, a pesquisa acadêmica e as avaliações técnicas, elas são fundamentais para que nós possamos agir, seja no âmbito extrajudicial ou judicial, para instar os nossos gestores locais a adotar providências e medidas mais restritivas para proteção das abelhas. (ABELHAS, Globo Rural, 28 jun. 2020, grifo nosso).

As pesquisas, conforme a fala da promotora Nakamura, são como um motor que impulsiona as ações do MPE/PA e, certamente, dos demais órgãos e instituições públicas.

À pergunta se as barreiras realmente desinfetam, o que se pode supor é que, sim, elas desinfetam. A desinfecção não acontece sozinha, mas é a parte final de um processo complexo e com várias etapas que devem ser entendidas e bem realizadas. Há uma espécie de protocolo que, se rigorosamente seguido, resultará na fase final: a desinfecção. Os passos precedentes são: limpeza, lavagem e enxágue. Isso está explícito na transcrição abaixo, cujo estudo é da EMBRAPA Clima Temperado, com sede em Pelotas-RS. 
A limpeza consiste na remoção de sujidades como matéria orgânica e detritos acumulados, podendo ser realizada manualmente ou mecanicamente. $\mathrm{O}$ procedimento reduz consideravelmente a carga bacteriana presente nessas superfícies e é decisivo para o sucesso das etapas posteriores. Por sua vez, a lavagem remove remanescentes com auxílio de água e detergentes, eliminando grande parte da contaminação presente. Durante o enxágue acontece a remoção, com água, do detergente utilizado. A retirada do detergente é importante para não gerar resíduos que possam interferir na ação do desinfetante. Finalmente, a desinfecção é uma prática preventiva muito importante nas criações intensivas. Os desinfetantes são substâncias químicas capazes de destruir a maioria e, eventualmente, a totalidade dos microrganismos na sua forma vegetativa; devem ser usados por tempo determinado e na concentração da solução recomendada. A eficácia do desinfetante é influenciada pela temperatura e seu tempo de ação. [...] (PEGORARO, 2018, p. 35)

Considerando-se as mesmas orientações da autora acima, pode afirmar-se que a adoção de tais estruturas ajudará no combate à disseminação do novo coronavírus.

À pergunta se o poder público fiscaliza as barreiras em questão, é possível dizer que não. Em matéria publicada no G1, sobre as mudanças no INMETRO ${ }^{12}$, o presidente do órgão, Gustavo Kuster, disse em entrevista a Silveira (2019): “Apenas 10\% de todo o escopo regulatório do INMETRO é regulado". E Silveira (2019) acrescentou: "Isso significa que 90\% dos produtos e serviços no país não têm normas regulatórias.” Nessas condições é que se arrisca dizer que entre os $90 \%$ não regulados encontram-se também as barreiras discutidas neste artigo.

O pedilúvio foi aperfeiçoado e subdividido em individual e coletivo. É produzido em diversos formatos, materiais e tamanhos. Assim, foi levado para frigoríficos e indústrias alimentícias, onde desinfeta os calçados de quem entra nesses ambientes. A fim de ilustrar e para que se conheçam alguns tipos existentes no país, que se observem as figuras abaixo.

Figura 07: Pedilúvio individual - espécie de tapete de espuma desinfetante.

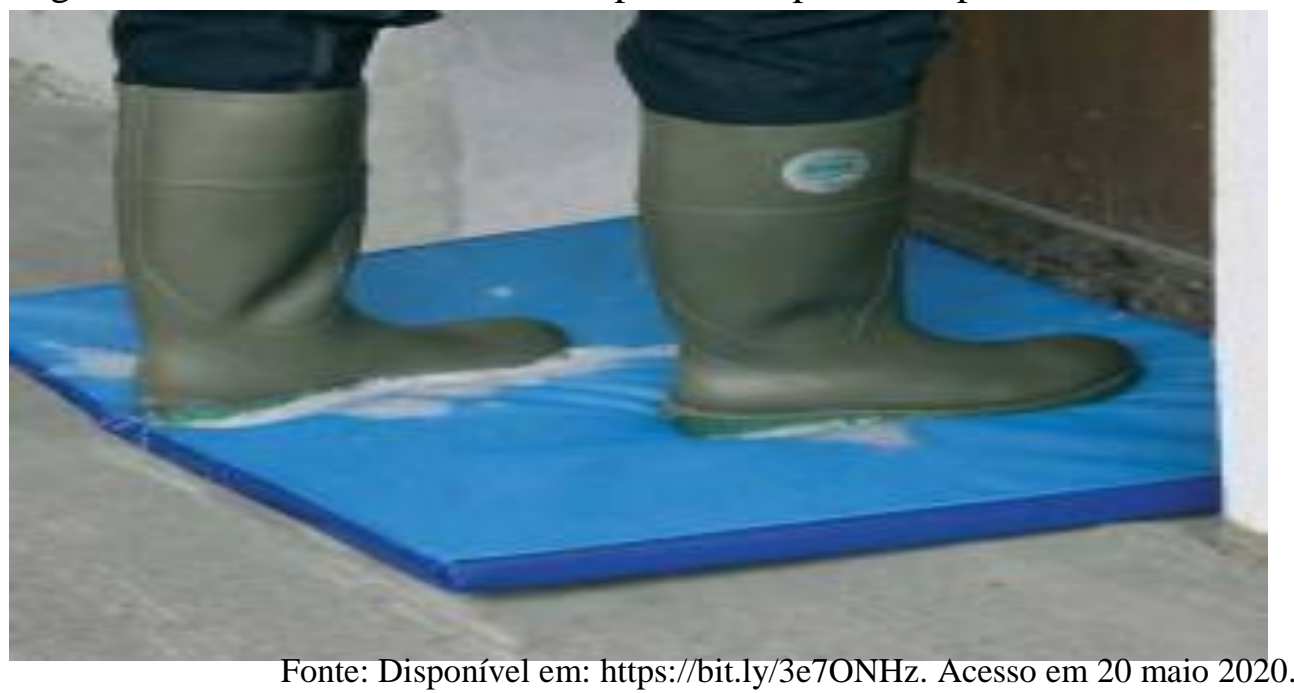

12 O SINMETRO, o CONMETRO e o INMETRO foram criados pela Lei 5.966, de 11 de dezembro de 1973 , com o objetivo de integrar uma estrutura sistêmica articulada. O INMETRO foi criado para substituir o então Instituto Nacional de Pesos e Medidas (INPM) e ampliar significativamente o seu raio de atuação a serviço da sociedade brasileira. Disponível em: https://bit.ly/3e5gwbT. Acesso em 12 mai.o 2020. 
Figura 08: Pedilúvio individual - tipo recipiente raso.

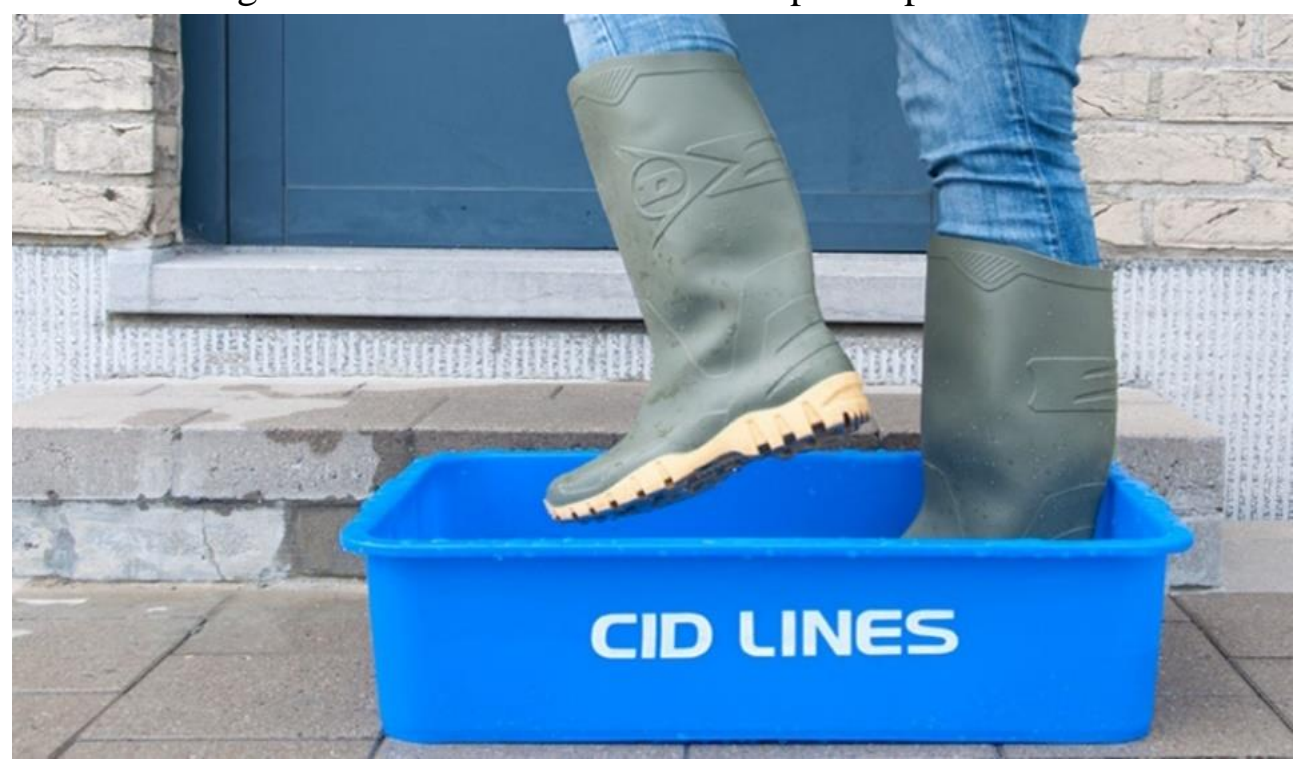

Fonte: Disponível em: https://binged.it/2Dfcpxr. Acesso em 20 maio 2020.

Há também o pedilúvio coletivo, conforme se vê na figura abaixo:

Figura 09: Pedilúvio coletivo. Foto desfocada para preservar identificações.

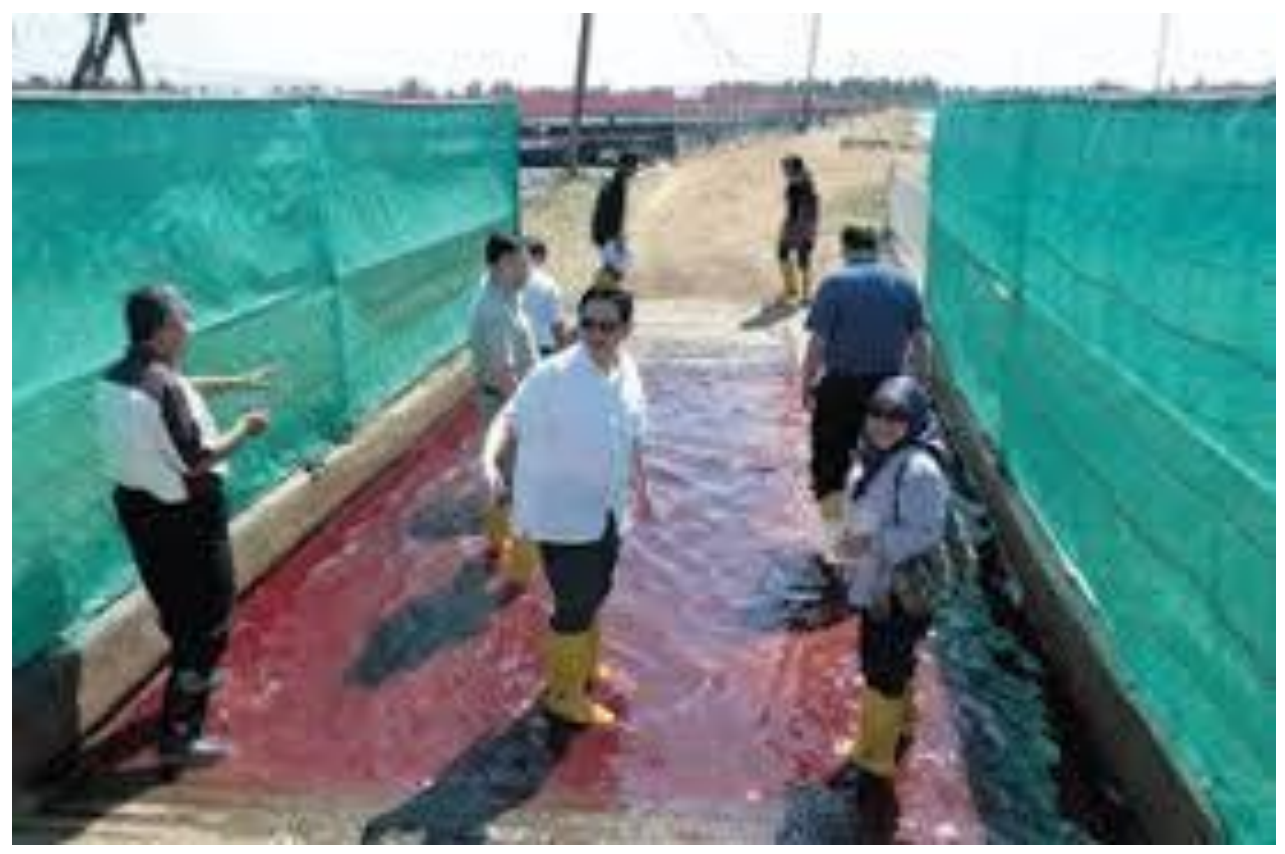

Fonte: (SOUZA, 2020)

Nos tipos de pedilúvio vistos acima, não há o que se vê no pedilúvio de Macedo (2013) ou de Ferreira (2010): uma massagem manual com água. Nas figuras acima não ocorre a lavagem à maneira de dilúvio, ou seja, pela força da água. Esse pequeno detalhe é o que separa o pedilúvio da literatura daquelas estruturas ou recipientes rasos do meio rural. 
No caso do arco de desinfecção, sua produção é em aço inox, aço galvanizado e em PVC; há modelos que têm regulagem automática em altura, que permite desinfetar os veículos mais altos ${ }^{13}$. Dois inconvenientes dessa barreira ainda são os consumos de água e de energia elétrica. Tais problemas vêm sendo amenizados com o aperfeiçoamento dos bicos injetores e com a introdução de bomba elétrica mais potente e alimentada por energia solar.

\section{CONSIDERAÇÕES FINAIS}

Causou estranheza pesquisar e quase nada encontrar sobre estruturas que têm mais de meio século de existência, que são mencionadas com frequência em escassos estudos científicos e/ou em legislações municipais, estaduais e federais, e têm sido produzidas e aperfeiçoadas pela indústria. Apesar de tudo isso, ainda não foram estudadas em profundidade.

A breve história das barreiras sanitárias discutidas neste artigo, revela-se como causa para novos estudos. Ainda mais quando se vê diminuir o uso do rodolúvio, que em pouco tempo desaparecerá devido a sua substituição pelo arco de desinfecção. Vale acompanhar se o termo rodolúvio estará na próxima edição do Aurélio, pois assim será descartado seu esquecimento.

No caso da etimologia de pedilúvio, que não tem, stricto sensu, relação com animais e, lato sensu, com a agropecuária, o que se sugere é advertir que o vocábulo foi “emprestado" pelo meio rural e pelas Ciências Agrárias. Isso em nada alterará o uso das barreiras, mas preservará um pouco a língua culta de ser ensinada de modo equivocado.

Deve ficar claro que o sufixo -lúvio vem do latim luere, que significa lavar à maneira de dilúvio, e isso não ocorre no recipiente com desinfetante usado no meio rural, onde os animais passam rapidamente ou ficam parados por alguns segundos, sob a ação do desinfetante. O mesmo acontece no rodolúvio, onde os veículos não param, mas reduzem a velocidade. A breve definição do termo pedilúvio e o silêncio sobre o rodolúvio, ambos em Ferreira (2010), se evidenciam como ensinamentos mais eficazes na defesa da língua portuguesa no país.

No âmbito legal, chamou atenção a variedade de normas que mencionam as três barreiras, sendo o arco de desinfecção o menos citado. Imagine-se a situação dos legisladores tentando criar leis sobre aquilo que não sabem. $\mathrm{Na}$ área administrativa o que se vê são breves menções nas normas infralegais que tratam da agropecuária no país. Isso também surpreendeu porque os órgãos públicos costumam ter técnicos capacitados e que podem pesquisar o assunto, tal qual Pegoraro (2018), mas isso ainda não aconteceu no caso desse tipo de estrutura.

\footnotetext{
${ }^{13}$ A altura máxima de veículos: ônibus - 4,10m; caminhão - 4,30m. (inciso III do $§ 2^{\circ}$ da Resolução nº 318-CONTRAN,
} de 5 jun. 2009). 
Em se tratando da academia, a surpresa com a falta de pesquisas sobre o assunto foi constrangedora porque a Universidade é o locus da ciência. Até o momento não há pesquisa sobre tais barreiras. Se a academia não investiga, então a indústria, também sem estudos, produz. É o caso do túnel de desinfecção de pessoas, divulgado em março ou abril e que pouco tempo depois tornouse a primeira barreira sanitária com uso proibido em norma infralegal, conforme o inciso IX do Art $2^{\circ}$ da Port no 312-SES, de 12 maio 2020, de Santa Catarina.

Diante do exposto, o que se percebe é que as barreiras sanitárias aqui discutidas têm sido relevantes para a sociedade porque cumprem seus papeis de prevenção, combate e cura de rebanhos, aves, peixes, mariscos e plantações com as quais a população se alimenta. Tal relevância se vê também nas indústrias alimentícias que utilizam as mesmas barreiras.

Em relação ao meio ambiente, as três estruturas parecem não causar impactos consideráveis porque têm sido usadas em pequena escala. E o arco de desinfecção, com seus aperfeiçoamentos, tem dado atenção a três aspectos: não agressão ao meio ambiente, reutilização da água e baixo consumo de energia, inclusive com o uso de energia solar.

A intenção deste artigo, que está distante de esgotar o assunto, é incitar a reflexão sobre as barreiras sanitárias em questão, ainda mais com a atual pandemia do novo coronavírus; o mesmo é válido para o recente túnel de desinfecção de pessoas.

\section{REFERÊNCIAS}

ABELHAS. Globo Rural. Rio de Janeiro: Rede Globo, 22 jun. 2020. Programa de TV.

BAHIA. Secretaria de Agricultura Irrigação e Reforma Agrária. Agência de Defesa Agropecuária da Bahia (ADAB). Portaria no 114-ADAB, de 7 jul. 2002. Aprovou o Manual Técnico-Sanitário para realização de leilões de animais no território baiano. Disponível em: https://www. contabeis.com.br/ legislacao/14876/portaria-adab-114-2002/. Acesso em: 10 mai. 2020.

BARBOSA, Rui. Oração aos moços. 5a . Ed. Rio de Janeiro: Casa de Rui Barbosa, 1999.

BLACKBURN, Simon. Dicionário Oxford de Filosofia. Rio de Janeiro: Jorge Zahar Ed., 1997.

BRASIL. Ministério da Agricultura, do Abastecimento e da Reforma Agrária. Portaria no 711, de $1^{\circ}$ nov. 1995. Aprovou as Normas Técnicas de instalações e equipamentos para abate e industrialização de suínos. Publicado no DOU de 03 nov. 1995, Seção 1, Página 17625.

BRASIL. Ministério da Agricultura e do Abastecimento. Instrução Normativa n 04-MAA, de 30 dez. 1998. Disponível em: https://www.defesa.agricultura.sp.gov.br/legislacoes/instrucao-normativa-4de30-12-1998,733.html. Acesso em: 10 mai. 2020. 
BRASIL. Ministério da Agricultura, Pecuária e Abastecimento. Instrução Normativa no 60-MAPA, de 6 nov. 2002. Disponível em: https://www.defesa.agricultura.sp.gov.br/legislacoes/ instruçãonormativa-60-de-6-11-2002,567.html. Acesso em: 12 mai. 2020.

BRASIL. Conselho Nacional de Trânsito. Resolução no 318, de 5 jun. 2009. Estabelece limites de pesos e dimensões para circulação de veículos de transporte de carga e de transporte coletivo de passageiros em viagem internacional pelo território nacional. Disponível em: https://www. legisweb.com.br/legislacao/?id=111213. Acesso em: 12 mai. 2020.

BRASIL. Ministério da Agricultura, Pecuária e Abastecimento. Instrução Normativa no 31-MAPA, de 9 jun. 2011. Disponível em: https://www.defesa.agricultura.sp.gov.br/legislacoes/instru cao-normativamapa-n-31-de-29-de-junho-de-2018,1169.html. Acesso em: 10 mai. 2020.

CARDOSO, Fátima. Armas químicas e biológicas - A mesma ciência que inventou os inseticidas produz uma praga terrível: as armas químicas. Rio de Janeiro: G1. Disponível em: https://super.abril.com.br/ciencia/armas-quimicas-e-biologicas/. Acesso em: 12 maio 2020.

CURADO, Adriano. Transamazônica, uma rodovia que não leva a lugar nenhum. Conhecimento Científico, 22 maio 2019. Disponível em: https://conhecimentocientifico.r7.com/transamazonicarodovia/. Acesso em: 15 ago. 2020.

FERREIRA, Aurélio Buarque de Holanda. Dicionário Aurélio da Língua Portuguesa. 5. ed. Curitiba: Positivo, 2010.

LYRA, T.M.P; SILVA, J.A. A febre aftosa no Brasil, 1960-2002. Arq. Bras. Med. Vet. Zootec., v.56, n.5, p. 565-576, 2004.

MACEDO, Joaquim Manuel de. A moreninha. [Livro eletrônico]. São Paulo: DCL, 2013. (Coleção Grandes Nomes da Literatura). Disponível em: https://bitlybr.com/zSf73. Acesso em: 09 jul. 2020.

MARANHÃO. Agência Estadual de Defesa Agropecuária. Coordenadoria de Defesa Animal. Despacho no 068-2020-CDA/AGED-MA, de 07 ago. 2020. Recebido por e-mail em 12 ago. 2020.

MATO GROSSO DO SUL. Secretaria de Estado de Meio Ambiente, Desenvolvimento Econômico, Produção e Agricultura Familiar (SEMAGRO). Portaria no 3.524, de $\mathbf{1}^{\mathbf{0}}$ dez 2015. Disponível em: https://www.legisweb.com.br/legislacao/?id=310764. Acesso em: 10 mai. 2020.

MINAS GERAIS. Secretaria Estadual de Agricultura, Pecuária e Abastecimento. Instituto Mineiro de Agropecuária. Portaria $\mathbf{n}^{\mathbf{0}}$ 1.217-IMA, de 30 maio 2012. Disponível em: https:// www.normasbrasil.com.br/norma/portaria-1217-2012-mg_241381.html. Acesso em: 10 mai. 2020.

MINAS GERAIS. Secretaria Estadual de Agricultura, Pecuária e Abastecimento. Instituto Mineiro de Agropecuária. Portaria no 1.391-IMA, de 6 jan 2014. Disponível em: https://www.legisweb. com.br/legislacao/?id=264269. Acesso em: 15 mai. 20202.

MORO, Nataniél Dal. O cotidiano dos caminhoneiros no oeste do Brasil. Revista Tempos Históricos, vol 16, $2^{\circ}$ semestre de 2012. Universidade Estadual do Oeste do Paraná. Campus de Marechal Cândido Rondon, p. 145-161, 2012.

PEDILÚVIO. In: Dicionário Priberam da Língua Portuguesa. Lisboa: Priberam Informática, 2008. Disponível em: https://dicionario.priberam.org/pedilúvio. Acesso em: 13 jun. 2020. 
PEGORARO, Ligia Margareth Cantarelli. Biosseguridade na bovinocultura leiteira. Ligia Margareth Cantarelli Pegoraro - Editora Técnica. Pelotas: EMBRAPA Clima Temperado, 2018. 45 p. Disponível em: https://ainfo.cnptia.embrapa.br/digital/bitstream/item/202288/1/Biossegu ridadePropriedade-Leiteira.pdf. Acesso em: 15 mai. 2020.

RECIFE. Secretaria Municipal de Saúde. Norma Técnica no 1-SESAU, de $1^{0}$ jun. 2017. Disciplina, no Município do Recife, as atividades relacionadas à importação, exportação, extração, fabricação, produção, manipulação, beneficiamento, acondicionamento, transporte, armazenamento, distribuição, embalagem, fracionamento, comercialização e uso de alimentos. Disponível em: https://www.legisweb.com.br/legislacao/?id=344302. Acesso em 10 jun. 2020.

REIS, José. Doença das aves. [Manual prático - No 3]. 3. ed. São Paulo: Melhoramentos, 1955.

RIO GRANDE DO SUL. Assembleia Legislativa. Decreto $\mathbf{n}^{\circ}$ 50.072, de 18 fev. 2013. Regulamenta a Lei $n^{\circ} 13.467$, de 15 jun. 2010, que dispõe sobre a adoção de medidas de defesa sanitária animal no âmbito do Estado do Rio Grande do Sul. Publicado no DOE n. ${ }^{\circ}$ 033, de 19 fev. 2013.

SANTA CATARINA. Secretaria Estadual de Saúde. Portaria no 312-SES, de 12 maio 2020. Estabelece medidas de prevenção para o funcionamento dos estabelecimentos de abatedouros frigoríficos de carnes em Santa Catarina. Disponível em: https://www.legisweb.com.br/legisla cao/?id=395249. Acesso em: 9 jun. 2020.

SILVEIRA, Daniel. Selo do Inmetro poderá deixar de ser exigido em produtos comercializados no Brasil. Rio de Janeiro: G1. Disponível em: https:/g1.globo.com/economia/noticia/ 2019/07/25/selo-do-inmetro-podera-deixar-de-ser-exigido-em-produtos-comercializados-nobrasil.ghtml. Acesso em: 12 mai. 2020.

SÃO PAULO. Secretaria de Agricultura e Abastecimento. Resolução no 018-SAA, de 31 mar. 1998. Fixa normas complementares a serem observadas na promoção e fiscalização da defesa sanitária animal, a cargo da Secretaria de Agricultura e Abastecimento, em especial quando da realização dos denominados \" rodeios\".

SOUZA, Ivanilson Silva. Instalação de arco de desinfecção de veículos nas rodovias estaduais e federais de acesso ao Estado do Maranhão. São Luís: Ivanilson Silva Souza, 2020, 44 f., inédito.

WINCHESTER, Simon. O professor e o louco: uma história de assassinato e loucura durante a elaboração do dicionário Oxford. São Paulo: Companhia das Letras, 2009.

WEBER, Max. Ciência e política: duas vocações. São Paulo: Martin Claret, verão 2003. 